\title{
Relationship between Psychological Capital and Quality of Life: The Role of Courage
}

\author{
Giuseppe Santisi ${ }^{1, *}$, Ernesto Lodi ${ }^{2}$, , Paola Magnano ${ }^{3} \mathbb{(}$, Rita Zarbo ${ }^{3}$ and Andrea Zammitti ${ }^{1}$ (I) \\ 1 Department of Educational Sciences, University of Catania, 95124 Catania, Italy; zammitti.a@gmail.com \\ 2 Department of Humanities and Social Sciences, University of Sassari, 07100 Sassari, Italy; elodi@uniss.it \\ 3 Faculty of Human and Social Sciences, Kore University, Cittadella Universitaria, 94100 Enna, Italy; \\ paola.magnano@unikore.it (P.M.); zarborita1@gmail.com (R.Z.) \\ * Correspondence: gsantisi@unict.it; Tel.: +39-095-250-8020
}

Received: 25 April 2020; Accepted: 23 June 2020; Published: 28 June 2020

\begin{abstract}
Quality of life is a multidimensional concept, a construct influenced by objective and subjective factors that include the evaluation of functional, physical, social, and emotional aspects of the person. The recent contributions of positive psychology present the quality of life as a fundamental indicator for health promotion and prevention strategies. In the recent psychological studies about this topic, courage demonstrated to positively affect several work behavioral outcomes, personal identity, and prosocial actions. Courage promotes change, innovation, and coping skills to achieve aims, and it correlates positively with many individual resources. The aim of the study was to investigate, according to the positive psychology approach, the relationships between psychological capital and two dimensions of quality of life-life satisfaction and flourishing - with particular attention to the mediation function performed by courage. The research was attended by a convenience sample of 807 Italian workers, balanced by gender, belonging to public, private, and non-profit organizations, and recruited on a voluntary basis. Participants responded to a structured online questionnaire containing the following measures: Psychological Capital Questionnaire, Courage Measure, Satisfaction with Life Scale, and Flourishing Scale. Cronbach's alpha on each scale showed very good internal consistency. The collected data were analyzed according to a model of linear structural equations. In the first step, we conducted a confirmatory factor analysis (CFA) to test the model fit of the measurement model; in the second step, we verified the mediation hypothesis through Process v.3.1. Finally, the correlations were implemented using SPSS 20.0. The results showed that, in general, psychological capital predicts life satisfaction and flourishing, with an indirect mediation effect of courage only on flourishing. Two main conclusions emerged from the study: flourishing and life satisfaction are representative indicators of the quality of life; courage emerges as an important psychological resource that supports the individual to face and manage the uncertainties of the risk society.
\end{abstract}

Keywords: courage; quality of life; PsyCap; well-being; organizational behavior

\section{Introduction}

The framework of our study derives from different basilar and inter-connected theoretical approaches to the quality of life of the persons and to their psychological resources: quality of life, subjective and psychological well-being, and positive psychology. Eurostat [1] reported that "any measurement of quality of life should also extend to cover the subjective well-being of persons," and the positive psychology framework highlighted that the psychological resources are the people points of strength able to improve their subjective and psychological well-being [2]. In the VIA (Values in Action), a test on humans' potentialities and strength, Seligman [2] put courage and two of 
the components of psychological capital (optimism and hope) in the list of the 24 variables that can improve our well-being. In relation to the remaining two components of the psychological capital: (a) self-efficacy is the central variable of the socio-cognitive perspective on general and domain-specific well-being tested in educational and work contexts [3-6], and (b) resilience [7] has shown its role not only as a protective factor in facing adversities but also as a key factor to promote positive development and adjustment.

Quality of life is a multidimensional concept, a broader construct influenced by objective and subjective factors that include the evaluation of functional, physical, social, and emotional aspects of the person [8]. Quality of life is described by the World Health Organization [9] as "an individual's perception of their position in life in the context of the culture and value systems in which they live and in relation to their standards, goals and expectations" (p. 1403). The initial studies about quality of life were focused on "objective factors" (i.e., income, the numbers of services in a place, etc.), but over time the focus has shifted to the optimal and global functioning of the persons and their subjective evaluation of these dimensions.

This vision today is stronger for the advancement of positive psychology that, in a perspective of prevention and health promotion, has moved the research topic of many psychological disciplines toward the identification of the factors that promote the perception of well-being and allow to reach the highest level of quality of life [10]. Three philosophical approaches have addressed the description of what it means to have a good life [11]: (1) the congruence between the individual's life and their values or ideals; (2) the balancing between resources and needs of individuals; and (3) the individual's perception of having a good and desirable life. The last approach underlines the concept of life satisfaction, a cognitive sense of satisfaction with life that includes how people evaluate their way of life and interact in their life's contexts as the essential element in the evaluation of the quality of life [12].

Life satisfaction is affected by various factors, such as personality traits, behavioral characteristics, and cognitive processes [3,13], and is related to social, occupational, mental, and physical health outcomes $[14,15]$. Indeed, life satisfaction and different kinds of domain-specific satisfaction (i.e., job, educational, and social relationship satisfaction) are related to positive outcomes in many spheres of life $[16,17]$. Life satisfaction positively affects the subjective well-being (SWB), a concept that includes emotional responses to the events and cognitive assessments of one's feelings of satisfaction and fulfillment. This vision of well-being has its roots in the hedonistic conception of well-being that inspired research regarding individuals' subjective experience of their life. On the other hand, the perspective of eudemonic well-being, considering psychological well-being (PWB) in Ryff's theory [18], emphasizes the aspects of a valuable life, which involve six dimensions: self-acceptance, autonomy, personal growth, environmental mastery, relationships with others, and purpose in life. This framework underlines the salience of individuals' optimal psychological functioning (flourishing) in the eudemonic perspective as the basilar component in the evaluation of well-being [19,20]. Keyes [21] defines flourishing as the set of internal experiences and positive functioning in the relationship with the world and the ability to realize one's own potential and talents in society. In the recent research on well-being, and from a positive psychology perspective, Diener [22] has defined the construct of "flourishing" as composed of several components: engagement, competence perception, optimism, self-acceptance, meaning and purpose in life, being respected, significant relationships with others, and a significant role in others' lives. This vision of optimal functioning is included in both aspects of hedonistic and eudemonic well-being, corroborating the attempt of other authors to integrate the two perspectives on well-being [3,23-25].

Given these theoretical and research results, in the present study, we can consider two indicators of quality of life: life satisfaction and flourishing. 


\subsection{Psychological Capital in the Organizational Context: Relations with Quality of Life}

Psychological capital is an asset of individual characteristics and qualities that promote the expression of positive resources and talents and, from this point of view, can be considered close to the definition of eudemonic well-being. This construct supports people in effectively dealing with everyday life: acting proactively, trusting in their possibilities, and looking positively at the future scenarios without being discouraged by the difficulties. Luthans, Youssef, and Avolio [26] identified four dimensions of psychological capital: hope, self-efficacy, resilience, and optimism. Given the recent socio-economic changes, the focus on psychological capital becomes fundamental with people of working age because they are experiencing the heaviest consequences of the crisis period for their family and social responsibilities [27]. In recent decades, this concept has especially attracted the attention of scholars and professionals dealing with organizational contexts. Luthans and Peterson [28] showed that psychological capital was a predictor of work performance and success; Avey, Avolio, and Luthans [29], instead, found a strong relationship between workers' psychological capital and the ability to cope with problems in an original and creative way. Chen and Lim [30], in a sample of persons who lost their jobs, noted that psychological capital was positively associated with levels of employability and coping adaptive strategies focused on the problem and on active job searching.

Regarding the relationship with quality of life, already in 2007, Luthans and colleagues demonstrated that psychological capital increased job satisfaction as well as professional commitment and work performance. A meta-analysis conducted by Avey et al. [31] confirmed that psychological capital is positively associated with job satisfaction, psychological well-being, collaborative behavior, and positive work results, and it is negatively associated with anxiety, work-related stress, and non-adaptive behavior at work.

In very recent studies, the researchers underlined that psychological capital is a predictor of (1) job satisfaction, organizational commitment, and well-being in church ministers [32]; and (2) subjective well-being and career commitment in public employees [33]. These results confirm another study conducted among public employees by Culbertson, Fullagar, and Mills [34] where psychological capital was associated with levels of well-being and satisfaction. In a study on university teachers, Li [35] underlined the effect of psychological capital on well-being (partially mediated by meaning in life); another study conducted on school teachers [36] showed that psychological capital was positively associated with job satisfaction and negatively to the burnout. Psychological capital is also a predictor of job engagement and has a negative effect on job burnout and psychological distress [37].

A very recent training [38] centered on increasing psychological capital among the unemployed showed that the intervention positively affected job-search behavior, enhancing well-being. Moreover, in a longitudinal study taking place over three years, Heinitz, Lorenz, Schulze, and Schorlemmer [39] demonstrated that self-efficacy and optimism had a positive effect on subjective well-being and that optimism had a positive effect on relieving depressive symptoms. In addition, all psychological capital dimensions showed a significant relation with flexible goal adjustment.

Finally, the relationship of psychological capital with well-being (or other variables related to domain-specific achievement) has been demonstrated in other contexts besides work, for example, with college students. In this context, psychological capital was associated with not only academic achievement but also academic satisfaction [40]. Another study on psychological capital highlighted that it mediates the relationship between study-related positive emotions and academic performance [41].

\subsection{Courage and Well-Being}

Although the concept of courage has been speculated on since 400 BC by ancient Greek philosophers, the role of courage as a psychological variable has only recently been analyzed by psychologists. For this reason, its precise definition represents the subject of various authors, especially those dealing with positive psychology. The capacity of persons to face the presence of fear is common in various definitions. In this way, Woodard [42] defined courage as the action aimed to pursue a meaningful cause, notwithstanding the feeling of fear due to the perception of a threat that is not easy 
to overcome. Furthermore, Woodard and Pury [43] emphasized the achievement of goals despite the presence of fear; Norton and Weiss [44] underlined the capacity of persisting during actions and perpetuating efforts despite fear; finally, Rachman [45] theorized courage as a behavioral approach in spite of fear experience. For several authors the construct of courage is multidimensional, for example, Putman $[46,47]$ theorized a classification of three courage types: physical, moral, and psychological. On the other hand, Rate, Clarke, Lindsay, and Sternberg [48] underlined four dimensions of acting courageously: (a) the action is intentional, (b) feelings of fear are present, (c) a noble purpose is present, and (d) the individual perceives a personal risk. Hannah, Sweeney, and Lester [49] underlined that courage is affected by personal strengths and resources (e.g., resilience, hope, and optimism), social influences, and personal beliefs and values.

In the few psychological studies about this topic, courage demonstrated to affect positively several work behavioral outcomes, personal identity, and prosocial actions, e.g., [50,51]. Courage promotes change, innovation [51], and coping skills to achieve one's aims [52] and correlates positively with many positive resources: career adaptability, self-efficacy, persistence, emotional intelligence, and resilience [53-56]. Moreover, in studies carried out on various age groups, courage has shown to be linked to higher levels of satisfaction, assertiveness, hope, open-mindedness, perseverance, motivation to pursue one's goals, and sense of gratitude and to lower levels of anxiety, discomfort, and irrational fears, e.g., [51,57-60]. An interesting study for the present research was conducted about the relationship between courage and quality of life. In studying the relationship between psychological capital and courage in entrepreneurial success, Bockorny [61] found that courage, beyond psychological capital, has a role in influencing life satisfaction. Other recent studies showed that courage is related to subjective well-being [61] and psychological well-being [62-64].

In the field of organizations, courage was studied in relation to leadership [65] and the competence to reach long-term goals [66], but apart from the construct of workplace courage, there are few studies with other working variables such as employability or meaningful work [67]. Which role can courage assume in a model that would consider psychological capital and the evaluation of well-being? Recent research has demonstrated that courage is a mediator in the relationship between career adaptability and life satisfaction [68] and between personality and coping [52]. Finally, some explorative studies found a strong relationship between courage and psychological capital and even suggested that courage may be a further constituent dimension of psychological capital $[60,69]$. For this reason and considering the Hannah and colleagues' [49] model of courage as behavior influenced by personal strengths and resources, we can suppose that courage can mediate the effect between psychosocial resources and quality of life.

A summary of the definitions relating to the key constructs and variables covered in the study is contained in Appendix A.

\section{Materials and Methods}

\subsection{Aims of Research}

Given that in previous research (1) psychological capital was a predictor of many dimensions involved in individual well-being and courage, as well as (2) showed its mediating role in the relationship between positive resources and individual well-being, we hypothesized that the effects of psychological capital on quality of life would be mediated by courage. In particular, the research hypotheses were as follows:

Hypothesis 1a. psychological capital positively affects life satisfaction.

Hypothesis 1b. psychological capital positively affects flourishing.

Hypothesis 2a. courage is a mediator of the effect of psychological capital on life satisfaction. 
Hypothesis $\mathbf{2 b}$. courage is a mediator of the effect of psychological capital on flourishing.

\subsection{Measures}

We measured the internal consistency of the scales using Cronbach's alpha; as stated in the pertinent literature $[70,71]$, alpha's values are considered not acceptable if $<0.60$; they are acceptable if between 0.60 and 0.70 ; alphas $>0.70$ are good; alphas $>0.80$ are very good.

\subsubsection{Courage Measure}

Courage was measured by Norton and Weiss' scale (Courage Measure; CM) [44], using the short version of Howard and Alipour [72,73] that describes courage as persistence despite fear. It is composed of six items with a 7-point Likert scale from 1 (never) to 7 (always); sample item: I will do things even though they seem to be dangerous. Cronbach's alpha of the study sample was 0.86 .

\subsubsection{Psychological Capital Questionnaire}

To measure positive psychological capital, we used a reduced version (12 items) of the original 24-item Psychological Capital Questionnaire (PCQ), [26,74,75]. This 12-item PCQ is composed of three items for efficacy, four items for hope (two agentic capacity, two pathways thinking), two items for optimism, and three items for resilience. This 12-item measure has been used in previously published research $[29,76]$. Sample items: (1) efficacy: I feel confident analyzing a long-term problem to find a solution; (2) hope: Right now I see myself as being pretty successful at work; (3) resilience: I usually manage difficulties one way or another at work; and (4) optimism: I'm optimistic about what will happen to me in the future as it pertains to work. Cronbach's alpha of the scale for the study sample was 0.92 .

\subsubsection{Satisfaction with Life Scale}

The satisfaction with life scale (SWLS) [13] evaluates general life satisfaction through an eight-item scale with a 7-point Likert scale from 1 (strongly disagree) to 7 (strongly agree). The Cronbach's alpha for the study sample was 0.90 .

\subsubsection{Flourishing Scale}

The flourishing scale [22] is a one-dimensional, eight-item scale with a 7-point Likert scale from 1 (strongly disagree) to 7 (strongly agree) that evaluates some aspect of personal adaptation that gives meaning to life (sample item: I lead a purposeful and meaningful life). The Cronbach's alpha for the study sample was 0.91 .

\subsection{Participants}

The participants were 807 Italian workers (male $=365,45.2 \%$; female $=442,54.8 \%$ ) aged between 18 and 67 years $(M=39.64 ; S D=11.67)$, both employed (660, $81.8 \%)$ and unemployed $(147,18.2 \%)$.

The respondents lived in various Italian regions. The majority of them had high school diplomas (331, $41 \%)$ and university degrees $(289,35.8 \%)$; some of them had postgraduate degrees $(126,15.6 \%)$; the remaining part had junior high school diplomas $(61,7.6 \%)$.

The respondents worked in public $(308,38.2 \%)$, private $(462,57.2 \%)$, and nonprofit $(37,4.6 \%)$ organizations. More than half of them had permanent contracts $(415,51.4 \%)$; the remaining part had fixed-term contracts $(170,21.1 \%)$ and other types of contracts $(222,27.5 \%)$.

The recruitment of the participants used convenience sampling; the participants were recruited on a voluntary basis, and they agreed to informed consent and were free to abandon their participation at any moment. The data collection was conducted in an anonymous way, using an online survey, through sending individual emails; the inclusion criterion was being employed or, if not, 
having previous working experience of at least six months. We collected the emails contacting several small and medium organizations (SMOs) in private and public jobs, selecting only the workers that gave their consent to send us the email contacts. Moreover, a part of the organizations published on their website the link with our questionnaire and a brief description of the research aim (that was to collect data about their experience and feelings as workers). At the end of the compilation of the questionnaires, the workers had the possibility to request an individual profile. To also collect the data of an unemployed sample, we published the link on several social networks. The women were more represented than men $(\mathrm{F}=366 ; 55.5 \% ; \mathrm{M}=294 ; 44.5 \%)$. The $56.7 \%(n=374)$ of the participants were married, and the percentage of education level was thus distributed as follows: $6,5 \%(n=43)$ junior high school diplomas; $41.4 \%(n=273)$ high school graduation; $34.4 \%(n=227)$ university degree; $17.7 \%(n=117)$ postgraduate degree. The respondents lived in different Italian regions.

The research project was approved by the IERB (Internal Ethical Review Board) of the University of Catania. The research survey was administered according to the ethical rules of the Italian Psychological Association.

\subsection{Data Analyses}

Data were analyzed using linear structural equation models (Lisrel 8.80 [77]). In the first step, we conducted a confirmatory factor analysis (CFA) to test the measurement model [78]. The goodness-of-fit indices used to confirm the adequacy of the structural model were chi-square $\left(\chi^{2}\right)$, comparative fit index $(\mathrm{CFI})$, and the root mean square error of approximation (RMSEA). The acceptable thresholds for the CFI are as follows: acceptable fit $>0.90$, good fit $>0.95$ [79]. According to Browne and Cudeck [80], an RMSEA $<0.09$ is still an indicator of a reasonable error of approximation in smaller samples.

In the second step, the verification of the mediation hypothesis was conducted using Process v.3.4 [81], through the bootstrapping method with 5000 repetitions; we reported the significance of the indirect effects with a confidence interval (CI) of 95\%.

Finally, the correlations were implemented using SPSS 25.0. To improve the sample size, we estimated the missing values for the relevant items through the expectation-maximization method. None of the items had more than $5 \%$ missing values, indicating this option suitable [82].

\section{Results}

\subsection{Descriptive Statistics and Correlations}

Table 1 presents the descriptive statistics of the measures used (PCQ, SWLS, flourishing, and courage). In Table 2, we report the correlations between the study variables verified through the Spearman's rho and Pearson's r coefficient, analyzing the relationships between psychological capital, courage, life satisfaction, and flourishing. Spearman's and Pearson's coefficients show similar values; all correlations presented in Table 2 are significant at $p<0.001$.

Table 1. Descriptive statistics of the variables.

\begin{tabular}{|c|c|c|c|c|c|c|c|c|}
\hline & & $\mathbf{M}$ & SD & Mdn & Min & Max & Skewness & Kurtosis \\
\hline 1. & PC & 5.15 & 0.99 & 5.25 & 1.92 & 7.00 & -0.72 & 0.30 \\
\hline 2. & SWL & 4.27 & 1.32 & 4.40 & 1.00 & 7.00 & -0.46 & -0.26 \\
\hline 3. & Flourishing & 5.17 & 1.07 & 5.38 & 1.25 & 7.00 & -1.17 & 1.89 \\
\hline 4. & Courage & 4.86 & 1.16 & 5.00 & 1.17 & 7.00 & -0.45 & -0.26 \\
\hline
\end{tabular}

Note. $\mathrm{PC}=$ psychological capital; $\mathrm{SWL}=$ satisfaction with life. 
Table 2. Spearman's (in italics) and Pearson's Correlations between the variables.

\begin{tabular}{|c|c|c|c|c|c|c|c|c|}
\hline & & & & & 2 & & & 4 \\
\hline 1. & PC & & & & & & & \\
\hline 2. & SWL & $0.43^{* * *}$ & $0.48^{* * *}$ & & 1 & & & \\
\hline 3. & Flourishing & $0.66^{* * *}$ & $0.72 * * *$ & $0.63^{* * *}$ & $0.68^{* * *}$ & & & \\
\hline 4. & Courage & $0.54^{* * *}$ & $0.56^{* * *}$ & $0.24^{* * *}$ & $0.27^{* * *}$ & $0.46^{* * *}$ & $0.48^{* * *}$ & 1 \\
\hline
\end{tabular}

Note. $\mathrm{PC}=$ psychological capital; $\mathrm{SWL}=$ satisfaction with life. ${ }^{* * *} p<0.001$.

\subsection{CFA of the Measures}

First, we tested the measurement model with a CFA using Lisrel 8.80. We conducted a CFA according to Harman's single-factor test to detect possible problems with the possibility of common method effects underlying observed results. We compared the hypothesized model and a model with one factor (with all items loading on a unique factor), finding that the 4 -factor model provided a better fit for the data in all of the CFA fit measures (4-factor model: $\chi^{2}{ }_{(428)}=2138.96 ; \mathrm{CFI}=0.97$; RMSEA $=0.07$; SRMR $=0.05 ; \mathrm{AIC}=2674.21 ; 1$-factor model $: \chi^{2}{ }_{(434)}=5910.81 ; \mathrm{CFI}=0.91 ; \mathrm{RMSEA}=0.17$; $\mathrm{SRMR}=0.10$, AIC $=10732$ ). The differences were significant according to a comparison of the models' $\chi^{2}$ values and degrees of freedom: $\Delta \chi^{2}{ }_{(6)}=3771.85(p<0.001)$. According to these results, we found no evidence for common method bias in the data.

The convergent validity was confirmed by the significant loading of the indicators on the hypothesized latent variables (factor loadings range $0.74-1.30 ; t>2.58$ ). Moreover, composite reliability $(\mathrm{CR}>0.85)$ showed excellent values for all of the constructs, and average variance extracted (AVE $>0.45)$ showed good values too.

\subsection{Structural Model and Mediational Analysis}

We tested our hypotheses using structural equation modeling analysis. Before describing the results, we have to be cautious in their interpretations because we cannot exclude completely the risk of reverse causality. Therefore, the literature on this topic underlines that the causal relationships are influenced by two factors: (1) time: the independent variables relate to a point earlier in time than the dependent ones; (2) a specific theoretical or concerning empirical data reason deriving from other previous studies $[83,84]$. Although we have adequate theoretical and empirical reasons deriving from previous studies, we cannot respect the first point with the research design used. Consequently, when we will refer to hypothetical causal relationships, we will have to consider these limitations.

The main fit indices are acceptable according the thresholds previously indicated, suggesting that the model fits the data $\left(\chi^{2}{ }_{(429)}=2402.62 ; \mathrm{CFI}=0.97\right.$; RMSEA $=0.08$; SRMR $\left.=0.07\right)$. The final model is presented in Figure 1. Standardized $\beta$, indicating the relationships between the variables, are all significant, except the path from courage to satisfaction with life. Thus, as represented in the figure, psychological capital shows both a direct effect and indirect effect on flourishing and has only a direct effect on life satisfaction; the indirect effects are mediated by courage. 


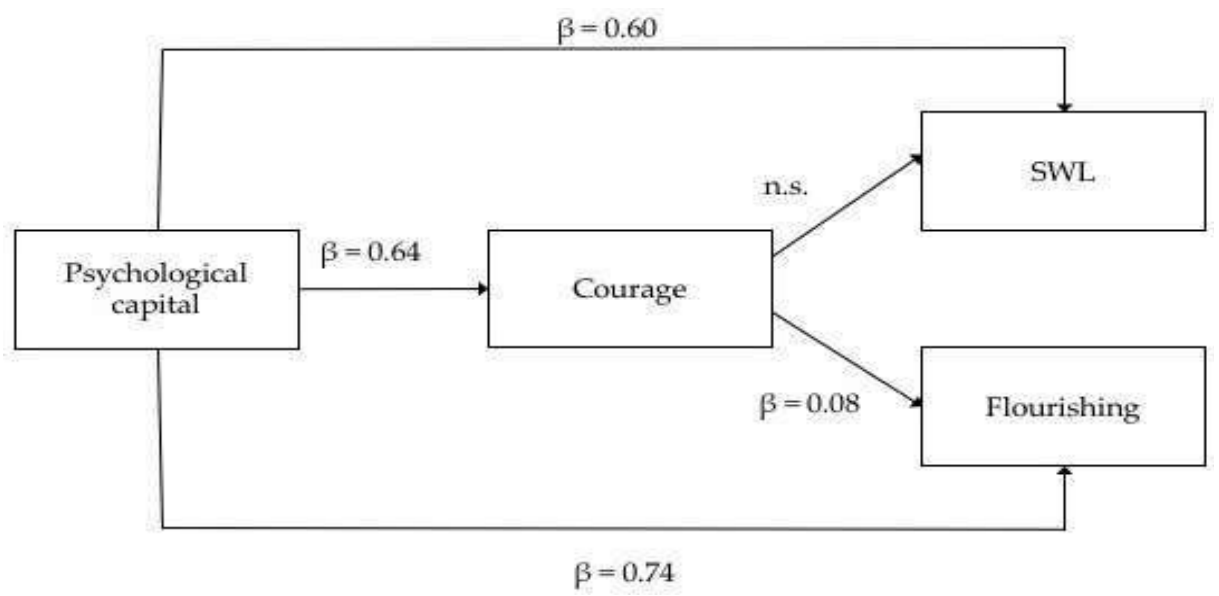

Figure 1. The final model.

We verified the mediational hypothesis by calculating the significance of the indirect effects through the bootstrapping method. In Table 3 are reported the standardized $\beta$ and the confidence intervals (CIs) 95\%, which indicate the significance of the effect with a 5\% probability of error (CI that does not comprise 0 is significant). The results, presented in Table 3 , show a direct effect of psychological capital on life satisfaction $(\beta=0.60, p<0.001)$ and flourishing $(\beta=0.74, p<0.001)$, confirming Hypothesis $1 \mathrm{a}$ and $1 \mathrm{~b}$; moreover, we found a direct and indirect effect of psychological capital on flourishing $(\mathrm{IE}=0.04 ; \mathrm{CI} 0.02-0.07)$ mediated by courage, as the path from psychological capital to courage was significant $(\beta=0.64, p<0.001)$, as well as the path from courage to flourishing $(\beta=0.08, p<0.001)$. The psychological capital showed only a direct effect on life satisfaction, as the path from courage to life satisfaction was not significant (these results did not confirm Hypothesis 2a).

Table 3. Effects of psychological capital on life satisfaction and flourishing through courage (standardized $\beta$ ). CI: confidence interval.

\begin{tabular}{ccccccc}
\hline Paths & \multicolumn{2}{c}{ Indirect Effect (IE) } & \multicolumn{2}{c}{ Direct Effect } & Total Effect \\
\hline $\begin{array}{c}\text { Psychological } \\
\text { Capital-Courage-Life } \\
\text { Satisfaction }\end{array}$ & $\beta$ & CI 95\% & $\beta$ & CI 95\% & $\beta$ & CI 95\% \\
\hline $\begin{array}{c}\text { Psychological } \\
\text { Capital-Courage-Flourishing }\end{array}$ & 0.01 & $-0.02-0.02$ & 0.27 & $0.22-0.31$ & 0.27 & $0.23-0.30$ \\
\hline
\end{tabular}

Accordingly, Hypotheses $1 \mathrm{a}, 1 \mathrm{~b}$, and $2 \mathrm{~b}$ were supported, while Hypothesis $2 \mathrm{a}$ was not supported by the data.

\section{Discussion}

The present study had the aim to verify the relationship between psychological capital, life satisfaction and flourishing, and the results showed the effects of psychological capital on one's quality of life could be mediated by courage. Data analysis, considering the limitation described before about the risk of reverse causality, seemed to support Hypotheses $1 \mathrm{a}, 1 \mathrm{~b}$, and 2b; but did not support Hypothesis 2a, showing a direct effect of psychological capital on both of the indicators of quality of life (life satisfaction and flourishing) and an indirect effect mediated by courage only on flourishing.

Regarding Hypotheses $1 \mathrm{a}$ and $1 \mathrm{~b}$, numerous studies have shown the positive effects of psychological capital on well-being in different contexts of life and work. In fact, as emphasized by Luthans et al. [85], psychological capital turns out to be a good predictor of satisfaction with important life domains such as work, relationships, and health. Much research has shown that higher levels of psychological capital correlate positively with better performance outcomes [26] and more commitment and well-being [29,76,86], and negatively with cynicism, turnover intention [29], 
and stress and anxiety [87]. Furthermore, it seems that the psychological capital can also have effects on some memory preservation and attention processes that have a long-term impact on well-being $[88,89]$.

Hypothesis 2, surprisingly, has been partially confirmed: courage was found to mediate the relationship between psychological capital and flourishing, but no mediation effect was found in the relationship between psychological capital and satisfaction with life. In a similar previous study [67], the mediational role of courage was shown either on the satisfaction with life or on the flourishing.

This is probably linked to the fact that courage was intrinsically constituted and aimed at a noble purpose [90-92], and this characteristic has a powerful effect on flourishing; considering that "psychological capital goes beyond human capital ('what you know') and social capital ('who you know'), and is more directly concerned with 'who you are' and more importantly 'who you are becoming'" [93] (p. 516), maybe courage, aimed at a noble purpose, plays a role in influencing the feeling of flourishing that is related to the meaning and purpose of life, and does not recover the same role in the satisfaction with life that requires a cognitive evaluation of the outcomes. We can probably link flourishing to the eudemonic aspect of well-being [22] and the satisfaction of life to the hedonistic dimension of well-being. We can link these results to the findings of Nelson et al. [94], who highlighted that flourishing levels are connected and influence greater increases by prosocial actions than self-focused or neutral behaviors: courage can be included in the first type of actions, even if in a broader meaning. Therefore, high levels of psychological capital, together with courage, can be useful to implement suitable and adaptive strategies in different situations supporting and promoting a higher quality of life that is considered as a global concept of well-being in different individual, social, and working contexts.

\section{Conclusions}

The results of the present study can be read in the framework of subjective well-being. In fact, the psychological capital can be considered a necessary resource in the management of the unpredictable and unforeseeable social and economic environment, which includes working environments, with the aim to improve two dimensions of the subjective well-being: flourishing and life satisfaction, which represent the indicators of quality of life [12,33,34,77].

Moreover, our study offers a contribution in the research on courage, which is demonstrated to be a mediator in the relationship between the dimensions cited above: courage is a behavioral construct and is featured by the presence of fear; it is linked to individuals' intentionality and pursues a significant goal; as highlighted in the text, courage may help people to face external problems and keep the willingness to do significant and meaningful things [95-97]. The risk society, requiring continuous life and work transitions, has the instability and uncertainty as distinguishing features [98]; frequent job and life transitions and the perceived risk for future prospects can be the source of feelings of fear. Courage is a psychological resource that can represent an adaptive behavior that helps individuals in dealing with demanding work contexts and giving meaning to those challenges [99].

Finally, we have to underline some limitations of the present study: first, it is a cross-sectional study, thus we cannot establish causal relationships between the variables and exclude the risk of reverse causality; second, the convenience sampling does not allow to consider the study's sample as representative; third, the participants were not equalized by age groups, educational level, type of organization, or employment status. Future studies could test the same model on different samples, i.e., managers or workers belonging to other cultural contexts. Moreover, future research could explore the moderating role of courage, analyzing the increasing or decreasing effect on flourishing and satisfaction with life. We also need longitudinal studies to demonstrate the causal relationships between variables.

Furthermore, other areas of research could explore the relationship between courage and organizational dimensions, such as workplace courage [50], psychosocial climate [100], or diversity climate [101]. 
Author Contributions: Conceptualization, G.S., P.M., and E.L.; methodology, P.M.; software, P.M.; investigation, R.Z.; data curation, P.M. and R.Z.; writing—original draft preparation, E.L., P.M., and R.Z.; writing—review and editing, G.S., P.M., and A.Z.; supervision, G.S. All authors have read and agreed to the published version of the manuscript.

Funding: This research received no external funding.

Conflicts of Interest: The authors declare no conflict of interest.

\section{Appendix A}

Table A1. Key constructs and variables of our study.

Quality of life is an individual's perception of their position in life in the context of the culture and value systems in which people live and in relation to their standards, goals, and expectations.

Flourishing is a set of internal experiences and positive functioning in the relationship with the world and the ability to realize one's own potential and talents in society. It is a basilar component in the evaluation of psychological well-being.

Life satisfaction is a component of quality of life and a cognitive dimension of subjective well-being. It is defined as a conscious cognitive judgment of own life in relation to a series of personally set criteria.

Courage is not ultimately defined by the literature. A definition useful for our study comes from Norton and Weiss [45] that have defined courage as the persistence and effort despite a subjective perception of fear.

PsyCap is an asset of individual characteristics that promote the expression of positive resources and talents. It is composed of 4 dimensions:

Hope is the ability to set goals, identify the strategies needed to achieve them, and the motivation towards the possibility of achieving certain results;

Optimism refers to the propensity to learn about experience and to build positive future scenarios. Optimism refers to how we explain the causes and implications of events in terms of internality;

Self-efficacy is the belief about the one's ability to behave effectively in order to achieve a goal or perform a task;

Resilience refers to the ability to persist even in the presence of failures and particularly negative events.

\section{References}

1. Eurostat 2020. Quality of Life Indicators-Overall Experience of Life. Available online: http://www.ec.europa.eu/eurostat/statistics-explained/index.php?title=Quality_of_life_indicators_-_ov erall_experience_of_life\#Overall_life_satisfaction_in_the_context_of_quality_of_life (accessed on 12 May 2020).

2. Seligman, M.E.P. Flourish: A Visionary New Understanding of Happiness and Well-Being; Atria Paperback: New York, NY, USA, 2013.

3. Lent, R.W.; Brown, S.D. Social cognitive career theory and subjective well-being in the context of work. J. Career Assess. 2008, 16, 6-21. [CrossRef]

4. Lent, R.W.; Singley, D.; Sheu, H.; Schmidt, J.A.; Schmidt, L.C. Relation of social-cognitive factors to academic satisfaction in engineering students. J. Career Assess. 2007, 15, 87-97. [CrossRef]

5. Lent, R.W.; Taveira, M.; Sheu, U.B.; Singley, H.D. Social cognitive predictors of academic adjustment and life satisfaction in Portuguese college students: A longitudinal analysis. J. Vocat. Behav. 2009, 74, $190-198$. [CrossRef]

6. Magnano, P.; Lodi, E.; Boerchi, D. The role of non-intellective competences and performance in college satisfaction. Interchange 2020. [CrossRef]

7. Masten, A.S.; Reed, M.G.J. Resilience in Development. In Handbook of Positive Psychology; Snyder, C.R., Lopez, S.J., Eds.; Oxford University Press: New York, NY, USA, 2002; pp. 74-88.

8. Gladis, M.M.; Gosch, E.A.; Dishuk, N.M.; Crits-Christoph, P. Quality of life: Expanding the scope of clinical significance. J. Consult. Clin. Psychol. 1999, 67, 320-331. [CrossRef]

9. The WHOQOL Group. The world health organization quality of life assessment (WHOQOL): Position paper from the world health organization. Soc. Sci. Med. 1995, 41, 1403-1409. [CrossRef]

10. Seligman, M.E.P. Positive Psychology, Positive Prevention, and Positive Therapy. In Handbook of Positive Psychology; Snyder, C.R., Lopez, S.J., Eds.; Oxford University Press: New York, NY, USA, 2002; pp. 3-9. 
11. Brock, D. Quality of life in health care and medical ethics. In The Quality of Life; Nussbuam, M., Sen, A., Eds.; Clarendon Press: Oxford, UK, 1993; pp. 95-132.

12. Diener, E.; Suh, E. Measuring Quality of Life: Economic, Social, and Subjective Indicators. Soc. Indic. Res. 1997, 40, 189-216. [CrossRef]

13. Diener, E.; Emmons, R.; Larsen, R.J.; Griffin, S. The satisfaction with life scale. J. Personal. Assess. 1985, 49, 71-75. [CrossRef]

14. Pavot, W.; Diener, E. Happiness Experienced: The Science of Subjective Well-Being. In The Oxford Handbook of Happiness; Oxford University Press: Oxford, UK, 2013; pp. 134-151.

15. Whisman, M.A.; Judd, C.M. A cross-national analysis of measurement invariance of the Satisfaction with Life Scale. Psychol. Assess. 2016, 28, 239. [CrossRef]

16. Lodi, E.; Boerchi, D.; Magnano, P.; Patrizi, P. College Satisfaction Scale (CSS): Evaluation of contextual satisfaction in relation to college student life satisfaction and academic performance. Appl. Psychol. Bull. 2017, 65, 51-64.

17. Wilkins, K.G.; Santilli, S.; Ferrari, L.; Nota, L.; Tracey, T.J.; Soresi, S. The relationship among positive emotional dispositions, career adaptability, and satisfaction in Italian high school students. J. Vocat. Behav. 2014, 85, 329-338. [CrossRef]

18. Ryff, C.D. Psychological well-being revisited: Advances in the science and practice of eudaimonia. Psychother. Psychosom. 2014, 83, 10-28. [CrossRef] [PubMed]

19. Keyes, C.L. The mental health continuum: From languishing to flourishing in life. J. Health Soc. Behav. 2002, 43, 207-222. [CrossRef]

20. Giuntoli, L.; Ceccarini, F.; Sica, C.; Caudek, C. Validation of the Italian version of the flourishing scale and of the scale of positive and negative experience. SAGE Open 2017, 7. [CrossRef]

21. Keyes, C.L.M. Promoting and protecting mental health as flourishing: A complementary strategy for improving national mental health. Am. Psychol. 2007, 62, 95-108. [CrossRef]

22. Diener, E.; Wirtz, D.; Tov, W.; Kim-Prieto, C.; Choi, D.W.; Oishi, S.; Biswas-Diener, R. New Well-being Measures: Short Scales to Assess Flourishing and Positive and Negative Feelings. Soc. Indic. Res. 2010, 97, 143-156. [CrossRef]

23. Huppert, F.A.; So, T.T. Flourishing across Europe: Application of a new conceptual framework for defining wellbeing. Soc. Indic. Res. 2013, 110, 837-861. [CrossRef]

24. Disabato, D.J.; Goodman, F.R.; Kashdan, T.B.; Short, J.L.; Jarden, A. Different types of well-being? A cross-cultural examination of hedonic and eudaimonic well-being. Psychol. Assess. 2016, 28, 471-482. [CrossRef]

25. Kashdan, T.B.; Biswas-Diener, R.; King, L.A. Reconsidering happiness: The costs of distinguishing between hedonics and eudaimonia. J. Posit. Psychol. 2008, 3, 219-233. [CrossRef]

26. Luthans, F.; Youssef, C.M.; Avolio, B.J. Psychology Capital; Oxford University Press: New York, NY, USA, 2007.

27. Santilli, S.; Nota, L.; Soresi, S. Psicologia Positiva e i Lavoratori di Oggi e del Prossimo Futuro [Positive Psychology and Workers of Today and Near Future]. In La Psicologia Positiva per L'orientamento e il Lavoro. Strumenti e Contributi di Ricerca; Nota, L., Soresi, S., Eds.; Hogrefe: Firenze, Italy, 2015; pp. 12-23.

28. Peterson, S.J.; Luthans, F. The positive impact and development of hopeful leaders. Leadersh. Organ. Dev. J. 2003, 24, 26-31. [CrossRef]

29. Avey, J.B.; Avolio, B.J.; Luthans, F. Experimentally analyzing the impact of leader positivity on follower positivity and performance. Leadersh. Q. 2011, 22, 282-294. [CrossRef]

30. Chen, D.J.; Lim, V.K. Strength in adversity: The influence of psychological capital on job search. J. Organ. Behav. 2012, 33, 811-839. [CrossRef]

31. Avey, J.B.; Reichard, R.J.; Luthans, F.; Mhatre, K.H. Meta-analysis of the impact of positive psychological capital on employee attitudes, behaviors, and performance. Hum. Resour. Dev. Q. 2011, 22, 127-152. [CrossRef]

32. Kanengoni, H.; Ngarambe, C.N.; Buitendach, J.H. Psychological capital and work behaviour-related outcomes among South African church ministers. S. Afr. J. Psychol. 2018, 48, 488-500. [CrossRef]

33. Singhal, H.; Rastogi, R. Psychological capital and career commitment: The mediating effect of subjective well-being. Manag. Decis. 2018, 56, 458-473. [CrossRef]

34. Culbertson, S.S.; Fullagar, C.J.; Mills, M.J. Feeling good and doing great: The relationship between psychological capital and well-being. J. Occup. Health Psychol. 2010, 15, 421-433. [CrossRef] 
35. Li, Y. Building well-being among university teachers: The roles of psychological capital and meaning in life. Eur. J. Work Organ. Psychol. 2018, 27, 594-602. [CrossRef]

36. Cheung, F.; Tang, C.S.K.; Tang, S. Psychological capital as a moderator between emotional labor, burnout, and job satisfaction among school teachers in China. Int. J. Stress Manag. 2011, 18, 348-371. [CrossRef]

37. Leon-Perez, J.M.; Antino, M.; Leon-Rubio, J.M. Adaptation of the short version of the Psychological Capital Questionnaire (PCQ-12) into Spanish. Rev. Psicol. Soc. 2017, 32, 196-213. [CrossRef]

38. Hulshof, I.L.; Demerouti, E.; Le Blanc, P.M. A job search demands-resources intervention among the unemployed: Effects on well-being, job search behavior and reemployment chances. J. Occup. Health Psychol. 2019, 25, 17-31. [CrossRef]

39. Heinitz, K.; Lorenz, T.; Schulze, D.; Schorlemmer, J. Positive organizational behavior: Longitudinal effects on subjective well-being. PLoS ONE 2018, 13, e0198588. [CrossRef] [PubMed]

40. Ortega-Maldonado, A.; Salanova, M. Psychological capital and performance among undergraduate students: The role of meaning-focused coping and satisfaction. Teach. High. Educ. 2018, 23, 390-402. [CrossRef]

41. Carmona-Halty, M.; Salanova, M.; Llorens, S.; Schaufeli, W.B. How psychological capital mediates between study-related positive emotions and academic performance. J. Happiness Stud. 2019, 20, 605-617. [CrossRef]

42. Woodard, C.R. Hardiness and the Concept of Courage. Consult. Psychol. J. 2004, 56, 173-185. [CrossRef]

43. Woodard, C.R.; Pury, C.L. The construct of courage: Categorization and measurement. Consult. Psychol. J. 2007, 59, 135-147. [CrossRef]

44. Norton, P.J.; Weiss, B.J. The role of courage on behavioral approach in a fear-eliciting situation: A proof-of-concept pilot study. J. Anxiety Disord. 2009, 23, 212-217. [CrossRef]

45. Rachman, S.J. Fear and courage: A psychological perspective. Soc. Res. Int. Q. 2004, 71, 149-176.

46. Putman, D.A. Psychological courage. Philos. Psychiatry Psychol. 1997, 4, 1-11. [CrossRef]

47. Putman, D.A. Philosophical Roots of the Concept of Courage. In The Psychology of Courage: Modern Research on an Ancient Virtue; Pury, C.L.S., Lopez, S.J., Eds.; American Psychological Association: Washington, DC, USA, 2010; pp. 9-22.

48. Rate, C.R.; Clarke, J.A.; Lindsay, D.R.; Sternberg, R.J. Implicit theories of courage. J. Posit. Psychol. 2007, 2, 80-98. [CrossRef]

49. Hannah, S.T.; Sweeney, P.J.; Lester, P.B. The Courageous Mind-Set: A Dynamic Personality System Approach to Courage. In The Psychology of Courage: Modern Research on an Ancient Virtue; Pury, C.S., Lopez, S.J., Eds.; American Psychological Association: Washington, DC, USA, 2010; pp. 125-148.

50. Howard, M.C.; Farr, J.L.; Grandey, A.A.; Gutworth, M.B. The creation of the workplace social courage scale (WSCS): An investigation of internal consistency, psychometric properties, validity, and utility. J. Bus. Psychol. 2017, 32, 673-690. [CrossRef]

51. Koerner, M.M. Courage as identity work: Accounts of workplace courage. Acad. Manag. J. 2014, 57, 63-93. [CrossRef]

52. Magnano, P.; Paolillo, A.; Platania, S.; Santisi, G. Courage as a potential mediator between personality and coping. Personal. Individ. Differ. 2017, 111, 13-18. [CrossRef]

53. Sovet, L.; Annovazzi, C.; Ginevra, M.C.; Kaliris, A.; Lodi, E. Life Design in Adolescence: The Role of Positive Psychological Resources. In New Perspectives on Career Counseling and Guidance in Europe; Cohen-Scali, V., Rossier, J., Nota, L., Eds.; Springer: Cham, Switzerland, 2018; pp. 23-37. ISBN 978-3-319-61475-5.

54. Hannah, S.T.; Sweeney, P.J.; Lester, P.B. Toward a courageous mindset: The subjective act and experience of courage. J. Posit. Psychol. 2007, 2, 129-135. [CrossRef]

55. Rachman, S.J. Fear and Courage, 2nd ed.; W.H. Freeman and Co.: New York, NY, USA, 1990; ISBN 9780716720614.

56. Magnano, P.; Santisi, G.; Platania, S. Emotional intelligence as mediator between burnout and organizational outcomes. Int. J. Work Organ. Emot. 2017, 8, 305-320. [CrossRef]

57. Ginevra, M.C.; Santilli, S.; Capozza, D. Coraggio Ed Età Evolutiva. In Counselling. Definizioni, Tassonomie, Metodologie, Costrutti, Tecniche e Strumenti; Soresi, S., Nota, L., Ginevra, M.C., Eds.; Cleup: Padova, Italy, 2016; pp. 167-176.

58. Muris, P. Fear and courage in children: Two sides of the same coin? J. Child Fam. Stud. 2009, 18, 486-490. [CrossRef] [PubMed]

59. Pury, C.L.S.; Kowalski, R.M.; Spearman, J. Distinctions between general and personal courage. J. Posit. Psychol. 2007, 2, 99-114. [CrossRef] 
60. Rachman, S.J. Fear and Courage; Freeman and Co.: New York, NY, USA, 1992.

61. Bockorny, K.M. Psychological Capital, Courage, and Entrepreneurial Success. Doctoral Dissertation, Bellevue University, Bellevue, NE, USA, 2015.

62. Leontopoulou, S.; Triliva, S. Explorations of subjective wellbeing and character strengths among a Greek University student sample. Int. J. Wellbeing 2012, 2, 251-270. [CrossRef]

63. Gustems, J.; Calderon, C. Character strengths and psychological wellbeing among students of teacher education. Int. J. Educ. Psychol. 2014, 3, 265-286. [CrossRef]

64. Toner, E.; Haslam, N.; Robinson, J.; Williams, P. Character strengths and wellbeing in adolescence: Structure and correlates of the Values in Action Inventory of Strengths for Children. Personal. Individ. Differ. 2012, 52, 637-642. [CrossRef]

65. Dvir, T.; Shamir, B. Follower developmental characteristics as predicting transformational leadership: A longitudinal field study. Leadersh. Q. 2003, 14, 327-344. [CrossRef]

66. Sarros, J.; Cooper, B. Building character: A leadership essential. J. Bus. Psychol. 2006, 21, 1-22. [CrossRef]

67. Magnano, P.; Santisi, G.; Zammitti, A.; Zarbo, R.; Di Nuovo, S. Self-Perceived Employability and Meaningful Work: The Mediating Role of Courage on Quality of Life. Sustainability 2019, 11, 764. [CrossRef]

68. Ginevra, M.C.; Magnano, P.; Lodi, E.; Annovazzi, C.; Camussi, E.; Patrizi, P.; Nota, L. The role of career adaptability and courage on life satisfaction in adolescence. J. Adolesc. 2018, 62, 1-8. [CrossRef] [PubMed]

69. Ke, J.L.; Sun, J.M.; Li, Y.R. Psychological capital: Chinese Indigenous Scale's development and its validity comparison with the Western Scale. Acta Psychol. Sin. 2009, 41, 875-888. [CrossRef]

70. Traub, R.E. Reliability for the Social Sciences: Theory and Applications; Sage: London, UK, 1994; Volume 777.

71. Kline, P. A Handbook of Psychological Testing, 2nd ed.; Routledge: London, UK, 1999.

72. Howard, M.C.; Alipour, K.K. Does the courage measure really measure courage? A theoretical and empirical evaluation. J. Posit. Psychol. 2014, 9, 449-459. [CrossRef]

73. Ginevra, M.C.; Santilli, S.; Camussi, E.; Magnano, P.; Capozza, D.; Nota, L. The Italian adaptation of courage measure. Int. J. Educ. Vocat. Guid. 2019, 1-19. [CrossRef]

74. Luthans, F.; Avolio, B.J.; Avey, J.B.; Norman, S.M. Positive psychological capital: Measurement and relationship with performance and satisfaction. Pers. Psychol. 2007, 60, 541-572. [CrossRef]

75. Alessandri, G.; Borgogni, L.; Consiglio, C.; Mitidieri, G. Psychometric Properties of the Italian Version of the Psychological Capital Questionnaire. Int. J. Sel. Assess. 2015, 23, 149-159. [CrossRef]

76. Luthans, F.; Avey, J.B.; Clapp-Smith, R.; Li, W. More evidence on the value of Chinese workers' psychological capital: A potentially unlimited competitive resource? Int. J. Hum. Resour. Manag. 2008, 19, 818-827. [CrossRef]

77. Jöreskog, K.G.; Sörbom, D. LISREL 8.80 for Windows; Computer Software, Scientific Software International: Lincolnwood, IL, USA, 2006.

78. Byrne, B.M. Structural equation modeling with AMOS, EQS, and LISREL: Comparative approaches to testing for the factorial validity of a measuring instrument. Int. J. Test. 2001, 1, 55-86. [CrossRef]

79. Hu, L.T.; Bentler, P.M. Cutoff criteria for fit indexes in covariance structure analysis: Conventional criteria versus new alternatives. Struct. Equ. Model. Multidiscip. J. 1999, 6, 1-55. [CrossRef]

80. Browne, M.W.; Cudeck, R. Alternative ways of assessing model fit. Test. Struct. Equ. Models 1993, 154, 136. [CrossRef]

81. Hayes, A.F.; Montoya, A.K.; Rockwood, N.J. The analysis of mechanisms and their contingencies: PROCESS versus structural equation modeling. Australas. Mark. J. 2017, 25, 76-81. [CrossRef]

82. Tabachnick, B.G.; Fidell, L.S. Using Multivariate Statistics, 5th ed.; Allyn \& Bacon/Pearson Education: Boston, MA, USA, 2007; ISBN 9780134790541.

83. Barbieri, P.; Raimondi, E.; Scherer, S. La Terza Forma a Priori Della Rappresentazione. L'inferenza Causale Nelle Scienze Sociali e la Congiunzione Spazio-Temporale Come Fine Ultimo Della Scienza Sociale. In Quaderni del Dipartimento di Sociologia e Ricerca Sociale; Università degli Studi di Trento: Trento, Italy, 2013; Available online: https://core.ac.uk/download/pdf/150084111.pdf (accessed on 20 June 2013).

84. Cox, D.R.; Wermuth, N. Some Statistical Aspects of Causality. Eur. Sociol. Rev. 2001, 17, 65-74. [CrossRef]

85. Luthans, F.; Youssef, C.M.; Sweetman, D.S.; Harms, P.D. Meeting the leadership challenge of employee well-being through relationship PsyCap and health PsyCap. J. Leadersh. Organ. Stud. 2013, 20, 114-129. [CrossRef] 
86. Avey, J.B.; Luthans, F.; Smith, R.M.; Palmer, N.F. Impact of positive psychological capital on employee well-being over time. J. Occup. Health Psychol. 2010, 15, 17. [CrossRef] [PubMed]

87. Avey, J.B.; Luthans, F.; Jensen, S.M. Psychological capital: A positive resource for combating employee stress and turnover. Hum. Resour. Manag. 2009, 48, 677-693. [CrossRef]

88. Diener, E.; Biswas-Diener, R. Happiness: Unlocking the Mysteries of Psychological Wealth; Blackwell: Malden, MA, USA, 2008.

89. Lyubomirsky, S. Why are some people happier than others? The role of cognitive and motivational processes in well-being. Am. Psychol. 2001, 56, 239-249. [CrossRef]

90. Cavanagh, G.F.; Moberg, D.J. The virtue of courage within the organization. Res. Ethical Issues Organ. 1999, 1, 1-25.

91. Goud, N.H. Courage: Its nature and development. J. Humanist. Couns. Educ. Dev. 2005, 44, 102-116. [CrossRef]

92. Rate, C.R.; Sternberg, R.J. When Good People Do Nothing: A Failure of Courage. In Research Companion to the Dysfunctional Workplace: Management Challenges and Symptoms; Langan-Fox, J., Cooper, C.L., Klimoski, R.J., Eds.; New Horizons in Management; Edward Elgar Publishing: Northampton, MA, USA, 2007; pp. 3-21.

93. Rahimnia, F.; Mazidi, A.; Mohammadzadeh, Z. Emotional mediators of psychological capital on well-being: The role of stress, anxiety, and depression. Manag. Sci. Lett. 2013, 3, 913-926. [CrossRef]

94. Nelson, L.J.; Padilla-Walker, L.M. Flourishing and floundering in emerging adult college students. Emerg. Adulthood 2013, 1, 67-78. [CrossRef]

95. May, D.R.; Chan, A.Y.; Hodges, T.D.; Avolio, B.J. Developing the moral component of authentic leadership. Organ. Dyn. 2003, 32, 247-260. [CrossRef]

96. Sosik, J.J.; Gentry, W.A.; Chun, J.U. The value of virtue in the upper echelons: A multisource examination of executive character strengths and performance. Leadersh. Q. 2012, 23, 367-382. [CrossRef]

97. Osswald, S.; Greitemeyer, T.; Fischer, P.; Frey, D. Moral prototypes and moral behavior: Specific effects on emotional precursors of moral behavior and on moral behavior by the activation of moral prototypes. Eur. J. Soc. Psychol. 2010, 40, 1078-1094. [CrossRef]

98. Craparo, G.; Magnano, P.; Paolillo, A.; Costantino, V. The Subjective Risk Intelligence Scale. The Development of a New Scale to Measure a New Construct. Curr. Psychol. 2018, 37, 966-981. [CrossRef]

99. Ramaci, T.; Bellini, D.; Presti, G.; Santisi, G. Psychological Flexibility and Mindfulness as predictors of individual outcomes in hospital health workers. Front. Psychol. 2019, 10, 1302. [CrossRef]

100. Magnano, P.; Santisi, G.; Platania, S.; Zammitti, A.; Tous, P.J. The Italian version of the Work Psychosocial Climate Scale (Escala Clima Psicosocial en el Trabajo). Work J. Prev. Assess. Rehabil. 2011. Available online: https://www.redalyc.org/pdf/970/97022648005.pdf (accessed on 28 June 2020).

101. Paolillo, A.; Pasini, M.; Silva, S.A.; Magnano, P. Psychometric properties of the Italian adaptation of the Mor Barak et al. diversity climate scale. Qual. Quant. 2017, 51, 873-890. [CrossRef]

(C) 2020 by the authors. Licensee MDPI, Basel, Switzerland. This article is an open access article distributed under the terms and conditions of the Creative Commons Attribution (CC BY) license (http://creativecommons.org/licenses/by/4.0/). 